\title{
A Simple, Cheap and Effective Method of Salvaging Sunken Logs
}

Translated from the Swedish of B. Wetterhall, in "Skogen," July, 1926

Several types of apparatus have been constructedespecially during the war years - for picking up sunken timber, but apparently none of these has been able to show practical results. Generally speaking, they are too expensive and they are not effective enough. Of course, most timber that sinks in shallow water, is salvaged with a grappling hook from a boat. This is a practical method; but the time wasted in towing a few logs ashore, often not more than two or three at once, makes it expensive, espacially when working a lung distance from land.

At a holding ground in Sweden, over a period of two summers, a method has been devised that makes it possible to pick up and hold about a hundred logs at a time, before towing to land, with only a grappling hook. This is a very inexpensive apparatus, simple, practical, and above all effective, and a short description may be of interest.

There pontoons of timber were built, made of three or four large logs joined together, each about fifteen inches at the top and seventeen feet long (if small dimensions are used, a double layer is necessary) Lengthwise along these pontoons, plank bridges are built, resting on $3^{\prime \prime} \times 9^{\prime \prime}$ planks set on edge (Fig. 1). The completed pontoons are arranged about ten feet I apart, parallel to one another, and are held in this こี E olank bridge connecting them across the middle of Dthe group of three, which forms the surface of the The bottom under the water should be fastened Tith with chains or wire (Fig. 2). The float is now ready for use.

For the actual salvaging, a grappling hook of ordinary type but larger size is used. The deeper the water the heavier the hook must be. Sometimes a spike with small teeth can be used to advantage. Fig. 3 shows the type and size of tools used. It is important that with a longer handle for deep water, the hook should be large and heavier; otherwise, it is difficult to get the hook far enough down to reach the submergeld $\operatorname{logs}$. It is wise to have a number of hooks of various sizes and weights.

The stretch of water to be worked should, if possible, be clear of floating logs, which can of course, be held with booms. Each float should be manned by three men, two of whom should have hooks with handles long enough to pick up logs from the bottom; and the third, a common shorter handled hook, with which to seize the log raised by the others and pull it into the empty space between the pontoons (shown in Figs. 4, 5, and 6).

The floats are anchored to a boom, either to one of the ordinary holding booms, or to an extra boom specially placed in the area to be worked. A point to be emphasized here is that in using a simple tool in deep water, where the bottom cannot be seen, better results are obtained than with more complicated apparatus.

When a $\log$ is located, the end of the hook or toothed snike is thrust into it, and it is easily dragged to the surface, to be caught by the man with the shorter hook and drawn into the empty space between the pontoons, resting on the bottom pieces connecting the pontoons a foot under the water, as described above. This is carried on as long as any timber remains in the area that can be reached from the float, which is then moved further down the boom to which it is anchored. When the whole area has been covered, the boom is moved; and so on until the whole of a holding ground has been worked. As already mentioned, a float of this size can salvage about a hundred logs at a time, by placing them in two layers between the pontoons; and, further, $\log s$ may be placed with one end resting on the float itself, already filled with logs. Of course, if the distance between the pontoons is greater than ten feet, more logs may be carried.

Thus loaded, the float is towed to the shore to discharge the salvaged timber. It is anchored as close as possible in a suitable place, - a beach or shoal is to be avoided; - and thus the timber is brought end on against the bank. Two men go ashore, and the third remains on the float, and the logs are pushed and hauled off in the ordinary way. It is to be noted that the salvaged timber is very smooth and slippery, making it very easy to handle.

In order to handle the salvaging of timber in this
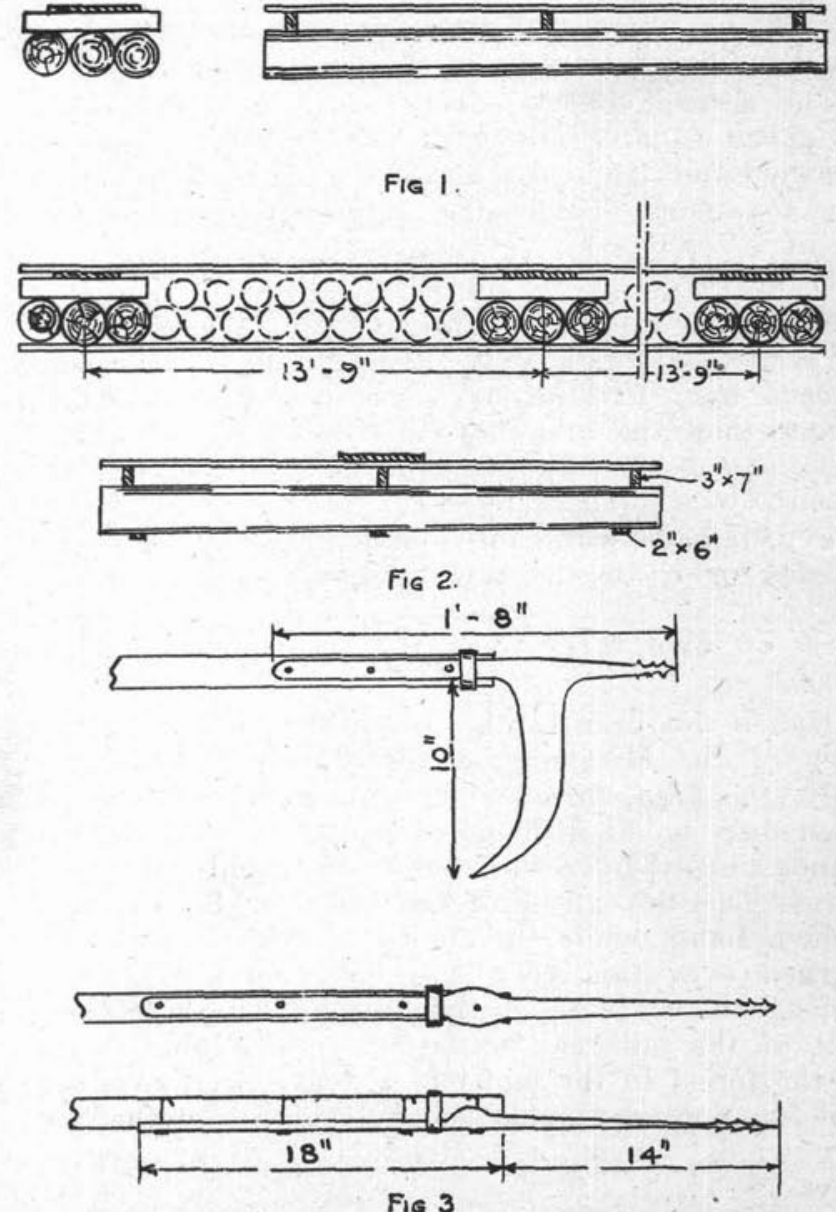
fashion, a certain degree of skill is necessary; therefore, it may be a little discouraging at first. But given sunken logs and a little enthusiasm, the apparatus will soon demonstrate its value-for the contractor as well as for the timber owner. Were more salvage work undertaken, the profit in logging would naturally be greater.

In a period of about six monthis in the territory where the experiment was tried, about 20,000 logs were picked, up in water varying in depth from 15 to 40 feet; in addition, several thousands were salvaged from shallower water. These logs, which had been lying on the bottom for a period of five to thirty years proved to be in remarkably good condition.

The cost of picking up and taking to shore was estimated at approximately nine cents per log, or about two cents per cubic foot, top measure.

The salvaged logs cannot of course be driven again, but must be hauled. In fact, since most of the sunken logs will be in the neighborhood of the mill or sorting gap, they can be taken directly in the above-described rafts to the cutting saws. This method of handling sunken timber iseems to offer a practical and economical way of salvage.

-Pulp and Paper Magazine

\section{ONLY 65 FIRES IN NEW BRUNSWICK}

Fredericton, N. B., October 12.-A new low record has been established this year for the number of forest fires in New Brunswick. Only 65 fires have been reported in the Province this year.

Statistics of the Forest Service of the Provincial Department of Lands and Mines show that the previous low total for any year was 143 fires reported in 1925. The number of fires for each of the past six years follows: 1920,$312 ; 1921,495 ; 1922,113 ; 1923$, $264 ; 1924,241 ; 1925,103$. These figures show an average of 254 per season for the period of six years; thus this season's number is only about $25 \%$ of the average. This greatly reduced number of fires is especially gratifying to all who are identified with the protection of the forests; it should also be gratifying to every citizen of New Brunswick, since only by reducing the number of fires can the annual loss that the Province suffers from this cause, be cut down.

The acreage burneid over has been 12,423 acresabout 20 square miles-of which 9562 acres was Crown Lands and 2861 acres private lands. The damage to timber based on stumpage values has been about $\$ 25,000$, while about $\$ 4000$ of property was also destroyed by the forest fires this year.

The area burned over during this season, strange to relate, although only $12 \%$ of the average area burned over for the six years preceding 1926, is larger than the area burned over in either 1922 or 1925, when 7374 and 6838 acres, respectively, were burned over. Omitting 1923, when exceptionally heavy damage was caused and 400,600 acres were burned over, the average acreage burned over for the past five years preceding 1926 , has been 41,931 acres, or over three times the area burned over this year.

Had it not been for a fire on the Sevogle, a tributary of the Miramichi River, during the month of July, the area burned over during 1926 would have been only about 4000 acres, and the area of Crown Lands burned over would have been only about 1000 acres. The Sevogle Fire burned over 8365 acres of Crown Land, while the total area of Crown Lands burned over this year was 9562 acres. The heavy damage in the case of the Sevogle Fire was the result of the outbreak of fire a considerable distance in the forest in the midst of a heavily cut over area; the fire spread quickly beyond control in the heavy dry winds, which blew steadily for five successive days.
Counties of the Province that suffered from fires during the 1926 season, together with the number of fires in each county were: Restigouche, 6; Gloucester, 7; Northumberland, 6; Kent, 1; Albert, 1; Sudbury, 1; York, 12; Victoria, 11; Madawaska. 8.

The above list does not include railway fires that occurred in various Counties, but caused little or no damage as a result of the increasingly efficient control of fire by the railway lines. Fire damage during the season just closed has been heaviest in Northumberland and Gloucester Counties; the fires in York and Restigouche Counties, while numerous, caused much less damage.

Lightning caused five of the 65 forest fires in New Brunswick during the past year; 12 fires were caused by railways, and the majority of the rest of the 65 outbreaks can be charged to the carelessness of persons traveling in the forests-that is, campers, fishermen, etc. In a number of cases, fires can be charged to persons who evidently went into the forests without registering and escaped the vigilance of the forest wardens. There was a reduction, however, of the fires caused by people traveling in the forests, over past seasons. Some attribute this to less forest travel, claiming that a late wet spring followed by hordes of black flies and mosquitos, kept many fishermen out of the forest, while many of those who made a trip into the streams did not have the hardihood to attempt a second one, on account of the flies. The late spring also shortened the fishing season, and the fishermen therefore had no reason to go into the woods at the time when their presence there would have been the greatest hazard. Then, again, more precautions have been taken this year in checking up on travelers in the forests, and in having as many as possible register before entering. Officials of the Forest Service maintain that the system of issuing forest-travel certificates is the surest kind of insurance against fires in the forest. Another feature in reducing $\log _{\mathrm{s}}$ from forest fires this year was the closing off the forests to public travel by proclamation by the Minister of Lands and Mines during two of the most hazardous periods - the first week in July and the first week in August. Had the forests been allowed to remain open during those two hazardous periods, it is altogether likely that there would have been a tremendous record of damage to report at this time. 